CLINICAL STUDY

\title{
Metabolic effects of overnight continuous infusion of unacylated ghrelin in humans
}

\author{
A Benso*, D H St-Pierre*, F Prodam ${ }^{1,2}$, E Gramaglia, R Granata, A J van der Lely ${ }^{3}$, E Ghigo and F Broglio \\ Division of Endocrinology, Diabetology and Metabolism, Department of Internal Medicine, Molinette Hospital, University of Turin, Corso Dogliotti 14, \\ 10126 Turin, Italy, ${ }^{1}$ Division of Pediatrics, Department of Medical Science and ${ }^{2}$ Division of Endocrinology, Department of Clinical and Experimental \\ Medicine, University of Piemonte Orientale, Novara, Italy and ${ }^{3}$ Division of Endocrinology, Department of Internal Medicine, Erasmus University of \\ Rotterdam, Rotterdam, The Netherlands
}

(Correspondence should be addressed to F Broglio who is now at SCDU Endocrinologia, Diabetologia e Metabolismo, Dipartimento di Medicina Interna, Università di Torino, AOU San Giovanni Battista Molinette, Corso Dogliotti 14, 10126 Torino, Italy; Email: fabio.broglio@unito.it)

*(A Benso and D H St-Pierre are joint first authors)

\begin{abstract}
Objective: To clarify the metabolic effects of an overnight i.v. infusion of unacylated ghrelin (UAG) in humans. UAG exerts relevant metabolic actions, likely mediated by a still unknown ghrelin receptor subtype, including effects on $\beta$-cell viability and function, insulin secretion and sensitivity, and glucose and lipid metabolism.

Design: We studied the effects of a 16-h infusion (from 2100 to $1300 \mathrm{~h}$ ) of UAG $(1.0 \mu \mathrm{g} / \mathrm{kg}$ per h) or saline in eight normal subjects (age (mean \pm s.E.M.), 29.6 \pm 2.4 years; body mass index (BMI), $22.4 \pm 1.7 \mathrm{~kg} / \mathrm{m}^{2}$ ), who were served, at 2100 and $0800 \mathrm{~h}$ respectively, with isocaloric balanced dinner and breakfast. Glucose, insulin, and free fatty acid (FFA) levels were measured every $20 \mathrm{~min}$.

Results: In comparison with saline, UAG induced significant $(P<0.05)$ changes in glucose, insulin, and FFA profiles. UAG infusion decreased glucose area under the curve (AUC) values by $10 \%\left(\mathrm{UAG}_{0-960 \mathrm{~min}}\right.$ : $79.0 \pm 1.7 \times 10^{3} \mathrm{mg} / \mathrm{dl}$ per min vs saline $\left.{ }_{0-960 \mathrm{~min}}: 87.5 \pm 3.8 \times 10^{3} \mathrm{mg} / \mathrm{dl} \mathrm{per} \mathrm{min}\right)$ and the AUC at night by $14 \%\left(\mathrm{UAG}_{180-660 \mathrm{~min}}: 28.4 \pm 0.5 \times 10^{3} \mathrm{mg} / \mathrm{dl}\right.$ per min vs saline $180-660 \mathrm{~min}: 33.2 \pm 1.1$ $\times 10^{3} \mathrm{mg} / \mathrm{dl}$ per min). The overall insulin AUC was not significantly modified by UAG infusion; however, insulin AUC observed after meals was significantly increased under the exposure to UAG with respect to saline at either dinner or breakfast. The FFA AUC values were decreased by $52 \%$ under the exposure to UAG in comparison with saline $\left(\mathrm{UAG}_{0-960 \mathrm{~min}}: 0.3 \pm 0.02 \times 10^{3} \mathrm{mEq} / \mathrm{l}\right.$ per min vs saline $_{0-960 \mathrm{~min}}: 0.6 \pm 0.05 \times 10^{3} \mathrm{mEq} / \mathrm{l}$ per min).

Conclusions: Exposure to the i.v. administration of UAG improves glucose metabolism and inhibits lipolysis in healthy volunteers. Thus, in contrast to the diabetogenic action of AG, UAG displays hypoglycemic properties.
\end{abstract}

European Journal of Endocrinology 166 911-916

\section{Introduction}

Ghrelin, the first natural hormone with an hydroxyl group of one of its serine residues acylated by $n$-octanoic acid $(1,2,3)$, is a 28 -amino acid residue peptide predominantly produced by the stomach but also expressed in several other sites, particularly in other enteric tracts and in the endocrine pancreas (4). In its acylated form, ghrelin displays a potent GH-releasing activity, mediated by the $\mathrm{GH}$ secretagogue receptor type 1a (GHS-R1a) $(4,5)$, that is concentrated in central and peripheral tissues, including the endocrine pancreas and the adipose tissue $(4,5,6)$. Consistently, ghrelin exerts other endocrine and nonendocrine actions either at the central or at the peripheral levels. In fact, ghrelin is now mostly recognized as a major orexigenic factor involved in several aspects of energy balance
$(7,8,9,10,11)$, exerting a stimulatory effect on appetite and food intake, while decreasing energy expenditure, and locomotor activity $(7,8,9,10,11)$.

Acylated ghrelin (AG) also exerts direct metabolic actions at the peripheral level, being able to influence the endocrine pancreatic function as well as glucose and lipid metabolism $(12,13,14)$. In particular, knockout animal models demonstrated a significant clear-cut improvement in glucose metabolism and insulin secretion and sensitivity in ghrelin and/or GHS-R1a null mice, which, moreover, were not phenotypically anorectic dwarf $(15,16,17)$.

On the other hand, although devoid of the GH-releasing effect, as well as of other neuroendocrine actions, ghrelin has been shown to exert a variety of biological actions in its unacylated ghrelin form (UAG) (18). In particular, several experiments suggest that 
UAG is able to positively modulate glucose and lipid metabolism $(19,20)$. In fact, the acute administration of UAG has been shown to antagonize the effects of AG on insulin secretion and glucose levels in normal subjects (19). At the same time, the combined administration of AG and UAG significantly improved insulin sensitivity, compared with placebo, for at least $6 \mathrm{~h}$ in patients with adult-onset GH deficiency (20).

Moreover, UAG counteracted the effects of AG on glucose output from pig hepatocytes in vitro (21) and, in glucose-stimulated conditions in vivo, exerted a potent insulin secretagogue action that was completely blocked by the coadministration of AG (22).

In addition to the effect on glucose homeostasis, it has also been demonstrated that UAG, as well as its acylated form, has an inhibitory effect on isoproterenol-induced lipolysis from rat adipocytes (23).

In all, it is clear that UAG is an active peptide, also able to bind to receptors other than GHS-R1a receptor $(4,18)$. In this context, also considering the mealrelated secretory pattern of circulating total ghrelin suggested by some authors (24), but not by others (25, $26)$, the negative association observed between body mass index (BMI) and ghrelin levels $(4,27)$, and their relationship with energy restriction and food intake $(4,8)$, insulin and glucose levels have been hypothesized to modulate peripheral ghrelin secretion that, in turn, is likely to influence insulin secretion and glucose metabolism $(13,28)$. Accordingly, total ghrelin levels have been shown to be reduced not only during an euglycemic hyperinsulinemic clamp and after insulininduced hypoglycemia $(8,29,30)$, but also after either an oral or i.v. glucose load $(8,29,31,32)$. Moreover, it has been hypothesized that UAG levels would be more remarkably reduced in obese patients and that this would significantly contribute to the reduction of insulin sensitivity (33).

The aim of this study was to clarify the metabolic effects of the prolonged i.v. infusion of UAG in humans. We studied the effects of a 16-h continuous infusion (from evening to the following early afternoon) of UAG or saline in normal young subjects, who were served a standard dinner and breakfast.

\section{Subjects and methods}

Eight normal young male volunteers (age (mean \pm s.E.M.) $29.6 \pm 2.4$ years; BMI, $22.4 \pm 1.7 \mathrm{~kg} / \mathrm{m}^{2}$ ) were studied. All subjects gave their written informed consent to participate in the study, which had previously been approved by an independent Ethics Committee.

All subjects underwent the following two testing sessions in random order at least 45 days apart: i) isotonic saline i.v. infusion for $16 \mathrm{~h}$; and ii) UAG $(1.0 \mu \mathrm{g} / \mathrm{kg}$ per h) i.v. infusion for $16 \mathrm{~h}$.
The infusion of UAG and placebo was double blind as it was performed by a third researcher. Subjects were admitted to the clinical facility $10 \mathrm{~h}$ before initiation of the testing session and were served an isocaloric lunch at $1300 \mathrm{~h}$. The testing sessions began in the evening at $2100 \mathrm{~h}, 30 \mathrm{~min}$ after the indwelling of two catheters into two different antecubital veins of the forearm, kept patent by the slow infusion of isotonic saline. At 2100 and $0900 \mathrm{~h}$ respectively, a standardized balanced isocaloric dinner ( 900 total kcal: 50\% carbohydrates, $20 \%$ proteins, and $30 \%$ lipids) and breakfast ( 400 total kcal: $50 \%$ carbohydrates, $10 \%$ proteins, and $40 \%$ lipids) were served to the subjects who were instructed to eat everything.

During the testing sessions, subjects were not allowed to drink alcohol, coffee, tea, or sweetened beverages or eat anything other than what they were provided with by the medical staff. All the subjects slept during the light-off period, although sleep was not instrumentally monitored. Lights were turned off at $2330 \mathrm{~h}$ and on at $0730 \mathrm{~h}$.

Blood samples were collected every $20 \mathrm{~min}$ from 2100 to $1300 \mathrm{~h}$ during the following day. Glucose, insulin, and free fatty acid (FFA) levels were assayed at each time point for both sessions.

Vials containing $100 \mathrm{mg}$ lyophilized human UAG were purchased from Neosystem and administered using a bacterial filter system.

Plasma glucose levels (mg/dl; $1 \mathrm{mg} / \mathrm{dl}, 0.05551 \mathrm{mmol} / \mathrm{l}$ ) were measured by the glucose oxidase colorimetric method (GLUCOFIX; Menarini Diagnostici, Florence, Italy).

Serum insulin levels $(\mu \mathrm{U} / \mathrm{ml})$ were measured in duplicate by immunoradiometric assay (INSIK-5; SORIN Biomedica, Saluggia, Italy). The sensitivity of the insulin assay was $2.5 \pm 0.3 \mu \mathrm{U} / \mathrm{ml}$. The inter- and intra-assay coefficients of variation (CV) were 6.2-10.8 and $5.5-10.6 \%$ respectively.

Serum FFA levels $(\mathrm{mEq} / \mathrm{l})$ were measured by enzymatic colorimetric method (Wako Chemicals GmbH, Neuss, Germany). The inter- and intra-assay CV were 1.1 and $4.1 \%$ respectively. All the samples from an individual subject were analyzed in a single run of each assay.

The results are expressed as absolute mean \pm s.e.m. The areas under the curves (AUC) of all variables were measured by the trapezoidal integration method for the whole infusion $(960 \mathrm{~min})$, the night time period (480 min), or the $60 \mathrm{~min}$ postprandial period. The $\triangle$ AUC values corrected for premeal levels were also calculated $(\triangle \mathrm{AUC})$. The differences observed between saline and UAG treatments were evaluated using the nonparametric Wilcoxon test. Statistical significance was assumed at $P<0.05$.

All statistical analyses were carried out using the SPSS 11.0 Software (SPSS, Chicago, IL, USA).

\section{Results}

The study subjects did not have any weight change between the two testing sessions (data not shown). 

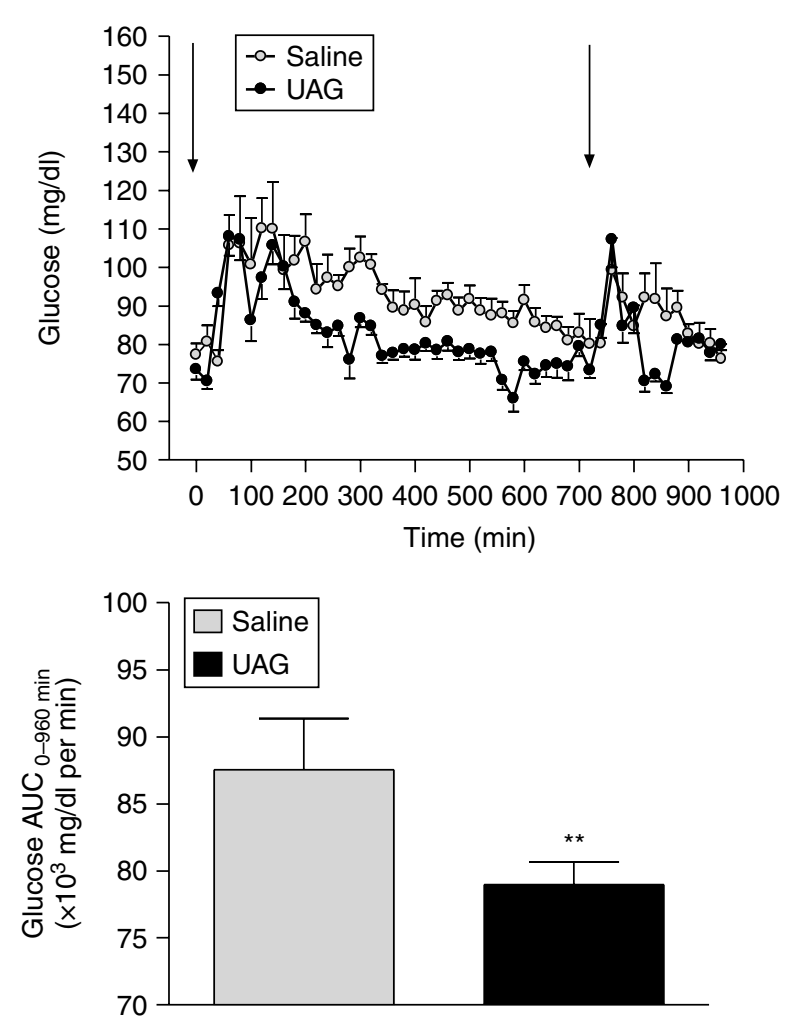

Figure 1 Glucose levels (mean \pm S.E.M.) expressed as absolute values and overall AUC ( $A \cup C_{0-960 ~ m i n}$ ) in eight young normal subjects during saline (gray) and UAG (black) i.v. infusion. The two vertical arrows correspond to the time of dinner and breakfast respectively. ${ }^{\star \star} P<0.01$ vs saline.

\section{Saline treatment}

As presented in Figs 1 and 2, during the saline infusion, glucose and insulin levels showed the expected increase after both dinner (absolute glucose peak: $110 \pm 7.9 \mathrm{mg} / \mathrm{dl}, \quad P<0.01$; glucose $\Delta \mathrm{AUC}_{0-60 \mathrm{~min}}$ : $317.5 \pm 145.0 \mathrm{mg} / \mathrm{dl}$ per $\min , \quad P<0.01$; absolute insulin peak: $57.8 \pm 14.7 \mu \mathrm{U} / \mathrm{ml}, \quad P<0.01$; insulin $\Delta \mathrm{AUC}_{0-60 \mathrm{~min}}: 232.0 \pm 116.2 \mu \mathrm{U} / \mathrm{ml}$ per min, $P<0.01$ ) and breakfast (absolute glucose peak: $115.5 \pm 6.8 \mathrm{mg} / \mathrm{dl}, P<0.05$; glucose $\Delta \mathrm{AUC}_{720-780 \mathrm{~min}}$ : $505.0 \pm 124.3 \mathrm{mg} / \mathrm{dl}$ per $\mathrm{min}, P<0.05$; absolute insulin peak: $46.3 \pm 9.5 \mu \mathrm{U} / \mathrm{ml}, P<0.05$; insulin $\Delta \mathrm{AUC}_{720-780 \mathrm{~min}}: 1078.4 \pm 124.3 \mu \mathrm{U} / \mathrm{ml}$ per $\mathrm{min}$, $P<0.05)$. In addition, as presented in Fig. 3, FFA levels decreased significantly $(P<0.05)$ after both dinner (absolute nadir, $0.6 \pm 0.1 \mathrm{mEq} / \mathrm{l} ; \Delta \mathrm{AUC}_{0-60 \mathrm{~min}}, 1.1$ $\pm 3.9 \mathrm{mEq} / \mathrm{l}$ per $\mathrm{min}$ ) and breakfast (absolute nadir, $0.5 \pm 0.1 \mathrm{mEq} / \mathrm{l} ; \quad \Delta \mathrm{AUC}_{720-780 \mathrm{~min}},-5.3 \pm 2.3 \mathrm{mEq} / \mathrm{l}$ per min).

\section{UAG treatment}

With respect to saline, the UAG infusion induced significant variations of all metabolic variables studied.
As presented in Fig. 1, during the 16-h UAG infusion, overall absolute glucose AUC values were lower on average by $10 \%$ with respect to saline (saline ${ }_{0-960 \mathrm{~min}}$ : $87.5 \pm 3.8 \times 10^{3} \mathrm{mg} / \mathrm{dl}$ per min vs $\mathrm{UAG}_{0-960 \mathrm{~min}}$ : $79.0 \pm 1.7 \times 10^{3} \mathrm{mg} / \mathrm{dl}$ per min; $P<0.01$ ), and this difference was even more pronounced during the nighttime period (0000-0800 h), when the absolute glucose AUC value was lower than saline by $14 \%$ (saline $_{180-660 \mathrm{~min}}: 33.2 \pm 1.1 \times 10^{3} \mathrm{mg} / \mathrm{dl}$ per $\min \mathrm{vs}$ $\mathrm{UAG}_{180-660 \mathrm{~min}}: 28.4 \pm 0.5 \times 10^{3} \mathrm{mg} / \mathrm{dl}$ per min; $P<0.01)$. Interestingly, this glucose-lowering effect was detected for the overall treatment at night but not during the $180 \mathrm{~min}$ postprandial periods following
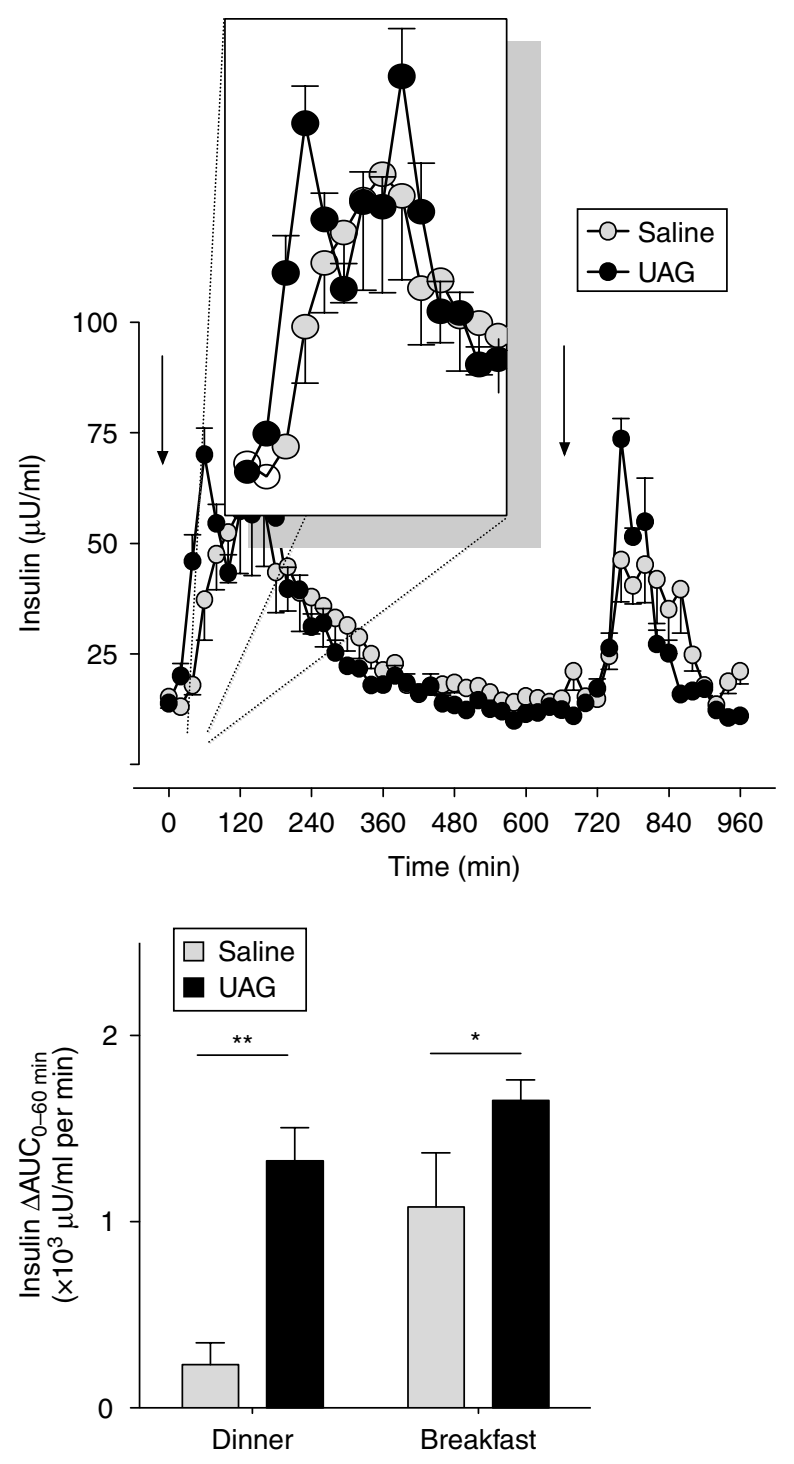

Figure 2 Insulin levels (mean \pm S.E.M.) expressed as absolute values and after meals $A \cup C\left(\triangle A \cup C_{0-60} \mathrm{~min}\right)$ in eight young normal subjects during saline (gray) and UAG (black) i.v. infusion. The two vertical arrows correspond to the time of dinner and breakfast respectively. The box in the top panel emphasizes the difference in the insulin response to dinner. ${ }^{\star} P<0.05$ vs saline; ${ }^{\star \star} P<0.01$ vs saline. 

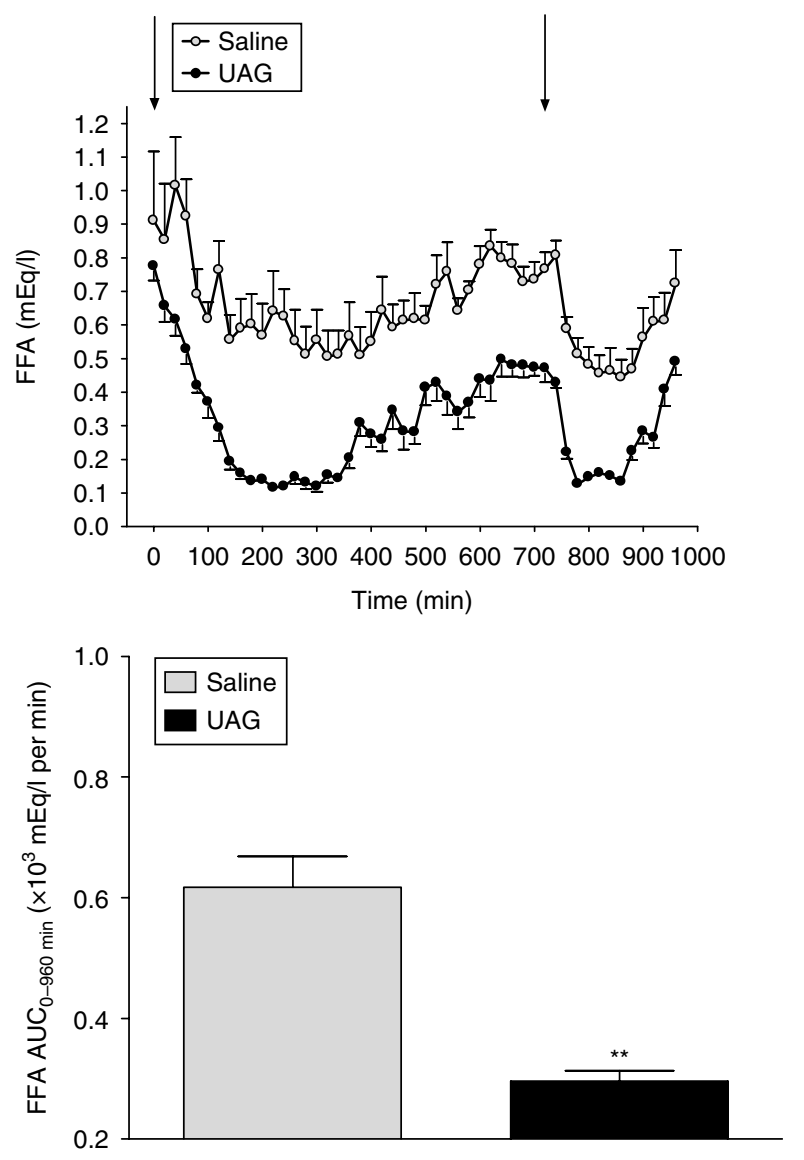

Figure 3 FFA levels (mean \pm S.E.M.) expressed as absolute values and overall AUC (AUC ${ }_{0-960 \mathrm{~min}}$ ) in eight young normal subjects during saline (gray) and UAG (black) i.v. infusion. The two vertical arrows correspond to the time of dinner and breakfast respectively. ${ }^{\star \star} P<0.01$ vs saline.

dinner $\left(\Delta\right.$ AUC saline $_{0-180 ~ m i n}: 3.7 \pm 1.0 \times 10^{3} \mathrm{mg} / \mathrm{dl}$ per min vs $\triangle$ AUC $\mathrm{UAG}_{0-180 \mathrm{~min}}: 3.8 \pm 0.3 \times 10^{3} \mathrm{mg} / \mathrm{dl}$ per min; $P=\mathrm{NS}$ ) or breakfast $\left(\Delta\right.$ AUC saline ${ }_{720-900 ~ m i n}$ : $1.5 \pm 0.7 \times 10^{3} \mathrm{mg} / \mathrm{dl}$ per min vs $\Delta \mathrm{AUC}^{\mathrm{U}} \mathrm{UAG}_{720-900 \mathrm{~min}}$ : $1.5 \pm 0.4 \times 10^{3} \mathrm{mg} / \mathrm{dl}$ per $\min ; P=\mathrm{NS}$ ).

Figure 2 indicates that, although the UAG infusion did not have significant impact on overall insulin concentrations during the $16-\mathrm{h}$ period (saline AUC $_{0-960 \text { min }}: 27.1 \pm 3.6 \times 10^{3} \mu \mathrm{U} / \mathrm{ml}$ per min vs UAG $\mathrm{AUC}_{0-960 \mathrm{~min}}: 26.5 \pm 1.8 \times 10^{3} \mu \mathrm{U} / \mathrm{ml}$ per min; $P=\mathrm{NS}$ ), there was a clear enhancing effect on insulin secretion immediately after both dinner $\left(\Delta \mathrm{AUC}\right.$ saline $_{0-60 \mathrm{~min}}$ : $0.2 \pm 0.1 \times 10^{3} \mu \mathrm{U} / \mathrm{ml}$ per min vs $\Delta \mathrm{AUC} \mathrm{UAG}_{0-60 \mathrm{~min}}$ : $1.3 \pm 1.8 \times 10^{3} \mu \mathrm{U} / \mathrm{ml}$ per $\left.\mathrm{min} ;+472 \% ; P<0.01\right)$ and breakfast $\left(\triangle \mathrm{AUC}\right.$ saline $_{720-780 \mathrm{~min}}: 1.1 \pm 0.3$ $\times 10^{3} \mu \mathrm{U} / \mathrm{ml}$ per min vs $\triangle \mathrm{AUC} \mathrm{UAG}_{0-60 \mathrm{~min}}: 1.7$ $\pm 1.1 \times 10^{3} \mu \mathrm{U} / \mathrm{ml}$ per min; $\left.+64 \% ; P<0.05\right)$.

As presented in Fig. 3, FFA AUC values decreased by $52 \%$ during the 16 -h UAG infusion $\left(\mathrm{UAG}_{0-960 \mathrm{~min}}\right.$ : $0.3 \pm 0.02 \times 10^{3} \mathrm{mEq} / \mathrm{l}$ per min vs saline $\mathrm{O}_{0-960 \mathrm{~min}}$ : $0.6 \pm 0.05 \times 10^{3} \mathrm{mEq} / \mathrm{l}$ per $\left.\min \right)$.

\section{Side effects}

No side effect was associated with saline infusion as expected. Similarly, UAG infusion was not associated with any significant adverse event. At the end of UAG infusion, without any evidence of cause-related effect, minimal facial edema was apparent in two subjects but disappeared within the following $2 \mathrm{~h}$. Blood pressure and pulse rate were monitored during the awaking period of saline and UAG infusion and their results were similar in the two testing sessions.

\section{Discussion}

Although AG, the only active transcript of the ghrelin gene, was considered for long time, some biological actions of UAG were observed both in vitro and in vivo, in animal as well as in human models $(4,13,14,18,28)$. Our study aimed to evaluate the effect of continuous i.v. administration of UAG on metabolic variables in healthy humans. We observed that in young healthy volunteers, the i.v. infusion of UAG significantly decreased glycemic profiles, particularly during nighttime. Also, UAG infusion was associated with an enhancement of the meal-induced early insulin response as well as with an impressive reduction in FFA levels. These metabolic variations occurred in the absence of any modifications of GH and cortisol levels (data not shown), in line with previous observations showing no neuroendocrine effect of UAG after acute administration $(12,18,19)$.

The reduction in glucose levels during UAG infusion in humans fits well with the previous studies indicating the glucose-lowering effect of the nonacylated form of ghrelin. In fact, it had been demonstrated in vitro that UAG reduces glucose output from pig hepatocytes (21); in this experimental model, UAG was also able to abolish the stimulatory effect on glucose output induced by AG and to partially counteract the stimulatory effect exerted by glucagon (21). Again, although unable to exert an acute hypoglycemic effect in fasted healthy volunteers following single i.v. bolus administration, it was demonstrated that UAG can abolish the hyperglycemic effect of AG in humans (19) and that the combined administration of AG and UAG significantly improved insulin sensitivity in patients with adult-onset GH deficiency (20).

The lowering of glucose profiles during exposure to UAG was associated with a more marked first-phase insulin response to meals and this might in part explain the observed favorable effect of UAG on glucose metabolism. AG can exert inhibitory effects on $\beta$-cell secretion and this has been reported by several groups from observations in both in vitro and in vivo studies in animal and human models $(13,14,28)$. In particular, AG seems to be able to decrease insulin secretion and its response to glucose and arginine in humans as well as in vitro in perfused pancreas $(4,13,14)$. Conversely, 
it has been shown that UAG, dose dependently, can stimulate insulin secretion from rat $\beta$-cells in vitro either in basal condition or in response to exposure to glucose (14), while it is able to counteract the inhibitory effect of AG on insulin levels in humans $(19,20)$.

It has to be emphasized that the endocrine pancreas is a natural source of ghrelin that is synthesized and secreted by a new pancreatic islet population defined as 'epsilon' $(\varepsilon)$ and that during fetal life the endocrine pancreas and not the stomach is the most important contributor of circulating ghrelin levels $(14,34)$. Within the endocrine pancreas, ghrelin, either acylated or not, likely plays a para/autocrine action on the regulation of insulin secretion (14). In fact, at the level of pancreatic endocrine islets, the presence of GHS-R1a as well as of the still uncharacterized ghrelin receptor subtypes has been demonstrated (14).

Thus, the ghrelin system is well represented in the endocrine pancreas, suggesting that it plays a relevant role in the modulation of insulin secretion. However, ghrelin might also play a role in the regulation of insulin sensitivity at the peripheral level $(4,8,13)$. In this context, it is noteworthy that the prevalence of ghrelin in its acylated form is associated with a worsening in insulin sensitivity in humans $(4,8,13)$. In fact, the ghrelin system has been suggested to be active in muscle and adipose tissue $(4,5)$. An example of these ghrelin effects on the adipose tissue is the remarkable inhibition of FFA levels that we observed during the infusion with UAG; this FFA decrease could partly explain the observed improvement in insulin sensitivity $(35,36)$. Actually, the observation of decreased FFA levels in our study does not necessarily imply an inhibition of lipolysis but could also suggest an increase in their tissutal uptake or inhibition of gastrointestinal fatty acid uptake and effects on hepatic fat metabolism. Nevertheless, our present findings fit well with the previous report that UAG inhibits isoproterenolinduced lipolysis (23) and stimulates lipid accumulation in human visceral adipocytes (37), as well as in murine preadipocyte cells (38). Interestingly, the inhibitory action on lipolysis seems to be the only common action for nonacylated ghrelin and AG $(18,23)$.

In summary, although a direct measurement of insulin sensitivity has not been performed, the results of this study, showing a concomitant reduction in insulin and glucose responses to meals, might support the hypothesis that UAG could play a metabolic role that improves glucose metabolism and insulin secretion and sensitivity and inhibits lipolysis in humans. All together, these data are consistent with transgenic animal models overexpressing UAG (39) as well as with a model of specific ghrelin-O-acyltransferase (MBOAT4) inhibition (40). In fact, on one hand, mice overexpressing UAG, under the control of the rat insulin II promoter in pancreatic islets, showed reduced blood glucose levels and increased insulin sensitivity, although in these models glucose-stimulated insulin secretion was reduced (39). On the other hand, normal mice treated with specific GOAT inhibitor, which are lacking AG but show normal or even enhanced levels of UAG, display improvement in glucose metabolism and insulin sensitivity (40).

In conclusion, we demonstrated that an overnight continuous i.v. administration of UAG improves glucose metabolism and inhibits lipolysis in healthy volunteers. This points toward a potential therapeutic role for UAG and its analogs in clinical conditions characterized by the presence of insulin resistance and metabolic derangement.

\section{Declaration of interest}

The authors declare that there is no conflict of interest that could be perceived as prejudicing the impartiality of the research reported.

\section{Funding}

This work has been supported by grants from the European Union (6th Framework Programme for Research, Technological Development and Demonstration; LSHM-CT- 2003-503041), PRIN 2005 (prot. 20005060517), and Università di Torino and Fondazione per lo Studio delle Malattie Endocrino-Metaboliche (FSMEM, Turin, Italy). D H St-Pierre has been supported by a postdoctoral award from the Canadian Institutes of Health Research (CIHR).

\section{Acknowledgements}

The authors wish to thank S Destefanis, C Gottero, and F Riganti for their contribution to the study. The skilful technical assistance of M Taliano, A Bertagna, and M C Ghigo is acknowledged.

\section{References}

1 Kojima M, Hosoda H, Date Y, Nakazato M, Matsuo H \& Kangawa K. Ghrelin is a growth-hormone-releasing acylated peptide from stomach. Nature 1999402 656-660. (doi:10.1038/45230)

2 Gutierrez JA, Solenberg PJ, Perkins DR, Willency JA, Knierman MD, Jin Z, Witcher DR, Luo S, Onyia JE \& Hale JE. Ghrelin octanoylation mediated by an orphan lipid transferase. PNAS 2008105 6320-6325. (doi:10.1073/pnas.0800708105)

3 Romero A, Kirchner H, Heppner K, Pfluger PT, Tschöp MH \& Nogueiras R. GOAT: the master switch for the ghrelin system? European Journal of Endocrinology 2010163 1-8. (doi:10.1530/ EJE-10-0099)

4 van der Lely AJ, Tschöp M, Heiman ML \& Ghigo E. Biological, physiological, pathophysiological, and pharmacological aspects of ghrelin. Endocrine Reviews 200425 426-457. (doi:10.1210/er. 2002-0029)

5 Korbonits M, Goldstone AP, Gueorguiev M \& Grossman AB. Ghrelina hormone with multiple functions. Frontiers in Neuroendocrinology 200425 27-68. (doi:10.1016/j.yfrne.2004.03.002)

6 Volante M, Allìa E, Gugliotta P, Funaro A, Broglio F, Deghenghi R, Muccioli G, Ghigo E \& Papotti M. Expression of ghrelin and of the GH secretagogue receptor by pancreatic islet cells and related endocrine tumors. Journal of Clinical Endocrinology and Metabolism 200287 1300-1308. (doi:10.1210/jc.87.3.1300)

7 Cummings DE. Ghrelin and the short- and long-term regulation of appetite and body weight. Physiology and Behavior $20068971-$ 84. (doi:10.1016/j.physbeh.2006.05.022)

8 Wiedmer P, Nogueiras R, Broglio F, D’Alessio D \& Tschöp MH. Ghrelin, obesity and diabetes. Nature Clinical Practice. Endocrinology and Metabolism 20073 705-712. (doi:10.1038/ncpendmet0625) 
9 Nogueiras R, Tschöp MH \& Zigman JM. Central nervous system regulation of energy metabolism: ghrelin versus leptin. Annals of the New York Academy of Sciences 20081126 14-19. (doi:10.1196/annals.1433.054)

10 De Vriese C, Perret J \& Delporte C. Focus on the short- and longterm effects of ghrelin on energy homeostasis. Nutrition 201026 579-584. (doi:10.1016/j.nut.2009.09.013)

11 Kojima M \& Kangawa K. Ghrelin: more than endogenous growth hormone secretagogue. Annals of the New York Academy of Sciences 20101200 140-148. (doi:10.1111/j.1749-6632.2010.05516.x)

12 Gasco V, Beccuti G, Marotta F, Benso A, Granata R, Broglio F \& Ghigo E. Endocrine and metabolic actions of ghrelin. Endocrine Development 201017 86-95. (doi:10.1159/000262531)

13 van der Lely AJ. Ghrelin and new metabolic frontiers. Hormone Research 200971 (Suppl 1) 129-133. (doi:10.1159/000178055)

14 Granata R, Baragli A, Settanni F, Scarlatti F \& Ghigo E. Unraveling the role of the ghrelin gene peptides in the endocrine pancreas. Journal of Molecular Endocrinology 201045 107-118. (doi:10. 1677/JME-10-0019)

15 Sun Y, Wang P, Zheng H \& Smith RG. Ghrelin stimulation of growth hormone release and appetite is mediated through the growth hormone secretagogue receptor. PNAS $2004 \mathbf{1 0 1}$ 4679-4684. (doi:10.1073/pnas.0305930101)

16 Sun Y, Asnicar M, Saha PK, Chan L \& Smith RG. Ablation of ghrelin improves the diabetic but not obese phenotype of $o b / o b$ mice. Cell Metabolism 20063 379-386. (doi:10.1016/j.cmet. 2006.04.004)

17 Sun Y, Butte NF, Garcia JM \& Smith RG. Characterization of adult ghrelin and ghrelin receptor knockout mice under positive and negative energy balance. Endocrinology 2008149 843-850. (doi:10.1210/en.2007-0271)

18 Soares JB \& Leite-Moreira AF. Ghrelin, des-acyl ghrelin and obestatin: three pieces of the same puzzle. Peptides 200829 1255-1270. (doi:10.1016/j.peptides.2008.02.018)

19 Broglio F, Gottero C, Prodam F, Gauna C, Muccioli G, Papotti M, Abribat T, van Der Lely AJ \& Ghigo E. Non-acylated ghrelin counteracts the metabolic but not the neuroendocrine response to acylated ghrelin in humans. Journal of Clinical Endocrinology and Metabolism 200489 3062-3065. (doi:10.1210/jc.2003-031964)

20 Gauna C, Meyler FM, Janssen JA, Delhanty PJ, Abribat T, van Koetsveld P, Hofland LJ, Broglio F, Ghigo E \& van der Lely AJ. Administration of acylated ghrelin reduces insulin sensitivity, whereas the combination of acylated plus unacylated ghrelin strongly improves insulin sensitivity. Journal of Clinical Endocrinology and Metabolism 200489 5035-5042. (doi:10. 1210/jc.2004-0363)

21 Gauna C, Delhanty PJ, Hofland LJ, Janssen JA, Broglio F, Ross RJ, Ghigo E \& van der Lely AJ. Ghrelin stimulates, whereas des-octanoyl ghrelin inhibits, glucose output by primary hepatocytes. Journal of Clinical Endocrinology and Metabolism 200590 1055-1060. (doi:10.1210/jc.2004-1069)

22 Gauna C, Kiewiet RM, Janssen JA, van de Zande B, Delhanty PJ, Ghigo E, Hofland LJ, Themmen AP \& van der Lely AJ. Unacylated ghrelin acts as a potent insulin secretagogue in glucose-stimulated conditions. American Journal of Physiology. Endocrinology and Metabolism 2007293 E697-E704. (doi:10.1152/ajpendo.00219. 2007)

23 Muccioli G, Pons N, Ghè C, Catapano F, Granata R \& Ghigo E. Ghrelin and des-acyl ghrelin both inhibit isoproterenol-induced lipolysis in rat adipocytes via a non-type 1a growth hormone secretagogue receptor. European Journal of Pharmacology 2004498 27-35. (doi:10.1016/j.ejphar.2004.07.066)

24 Cummings DE, Purnell JQ, Frayo RS, Schmidova K, Wisse BE \& Weigle DS. A preprandial rise in plasma ghrelin levels suggests a role in meal initiation in humans. Diabetes $2001501714-1719$. (doi:10.2337/diabetes.50.8.1714)

25 Barkan AL, Dimaraki EV, Jessup SK, Symons KV, Ermolenko M \& Jaffe CA. Ghrelin secretion in humans is sexually dimorphic, suppressed by somatostatin, and not affected by the ambient growth hormone levels. Journal of Clinical Endocrinology and Metabolism 2003 88 2180-2184. (doi:10.1210/jc.2002-021169)
26 Avram AM, Jaffe CA, Symons KV \& Barkan AL. Endogenous circulating ghrelin does not mediate growth hormone rhythmicity or response to fasting. Journal of Clinical Endocrinology and Metabolism 200590 2982-2987. (doi:10.1210/jc.2004-1785)

27 Tschöp M, Weyer C, Tataranni PA, Devanarayan V, Ravussin E \& Heiman ML. Circulating ghrelin levels are decreased in human obesity. Diabetes 200150 707-709. (doi:10.2337/diabetes.50.4.707)

28 Ukkola O. Ghrelin and metabolic disorders. Current Protein and Peptide Science 200910 2-7. (doi:10.2174/138920309787315220)

29 McCowen KC, Maykel JA, Bistrian BR \& Ling PR. Circulating ghrelin concentrations are lowered by intravenous glucose or hyperinsulinemic euglycemic conditions in rodents. Journal of Endocrinology 2002175 R7-11. (doi:10.1677/joe.0.175R007)

30 Möhlig M, Spranger J, Otto B, Ristow M, Tschöp M \& Pfeiffer AF. Euglycemic hyperinsulinemia, but not lipid infusion, decreases circulating ghrelin levels in humans. Journal of Endocrinological Investigation 200225 RC36-RC38.

31 Nakagawa E, Nagaya N, Okumura H, Enomoto M, Oya H, Ono F, Hosoda H, Kojima M \& Kangawa K. Hyperglycaemia suppresses the secretion of ghrelin, a novel growth-hormone-releasing peptide: responses to the intravenous and oral administration of glucose. Clinical Science 2002103 325-328.

32 Baldelli R, Bellone S, Castellino N, Petri A, Rapa A, Vivenza D, Bellone J, Broglio F, Ghigo E \& Bona G. Oral glucose load inhibits circulating ghrelin levels to the same extent in normal and obese children. Clinical Endocrinology 200664 255-259. (doi:10.1111/ j.1365-2265.2006.02441.x)

33 St-Pierre DH, Karelis AD, Coderre L, Malita F, Fontaine J, Mignault D, Brochu M, Bastard JP, Cianflone K, Doucet E, Imbeault P \& Rabasa-Lhoret R. Association of acylated and nonacylated ghrelin with insulin sensitivity in overweight and obese postmenopausal women. Journal of Clinical Endocrinology and Metabolism 200792 264-269. (doi:10.1210/jc.2006-1603)

34 Prado CL, Pugh-Bernard AE, Elghazi L, Sosa-Pineda B \& Sussel L. Ghrelin cells replace insulin-producing beta cells in two mouse models of pancreas development. PNAS $20041012924-2929$. (doi:10.1073/pnas.0308604100)

35 Kovacs P \& Stumvoll M. Fatty acids and insulin resistance in muscle and liver. Best Practice and Research. Clinical Endocrinology and Metabolism 2005 19 625-635. (doi:10.1016/j.beem.2005.07.003)

36 Frayes KN. Adipose tissue and the insulin resistance syndrome. Proceedings of the Nutrition Society 200160 375-380. (doi:10. 1079/PNS200195)

37 Rodríguez A, Gómez-Ambrosi J, Catalán V, Gil MJ, Becerril S, Sáinz N, Silva C, Salvador J, Colina I \& Frühbeck G. Acylated and desacyl ghrelin stimulate lipid accumulation in human visceral adipocytes. International Journal of Obesity 200933 541-552. (doi:10.1038/ijo.2009.40)

38 Miegueu P, St Pierre D, Broglio F \& Cianflone K. Effect of desacyl ghrelin, obestatin and related peptides on triglyceride storage, metabolism and GHSR signaling in 3T3-L1 adipocytes. Journal of Cellular Biochemistry 2011 112 704-714. (doi:10.1002/jcb.22983)

39 Iwakura H, Hosoda K, Son C, Fujikura J, Tomita T, Noguchi M, Ariyasu H, Takaya K, Masuzaki H, Ogawa Y, Hayashi T, Inoue G, Akamizu T, Hosoda H, Kojima M, Itoh H, Toyokuni S, Kangawa K \& Nakao K. Analysis of rat insulin II promoter-ghrelin transgenic mice and rat glucagon promoter-ghrelin transgenic mice. Journal of Biological Chemistry $2005 \quad 280 \quad 15247-15256$. (doi:10.1074/jbc.M411358200)

40 Barnett BP, Hwang Y, Taylor MS, Kirchner H, Pfluger PT, Bernard V, Lin YY, Bowers EM, Mukherjee C, Song WJ, Longo PA, Leahy DJ, Hussain MA, Tschöp MH, Boeke JD \& Cole PA. Glucose and weight control in mice with a designed ghrelin O-acyltransferase inhibitor. Science $20103301689-1692$. (doi:10.1126/science.1196154)

Received 14 November 2011

Revised version received 25 January 2012

Accepted 22 February 2012 